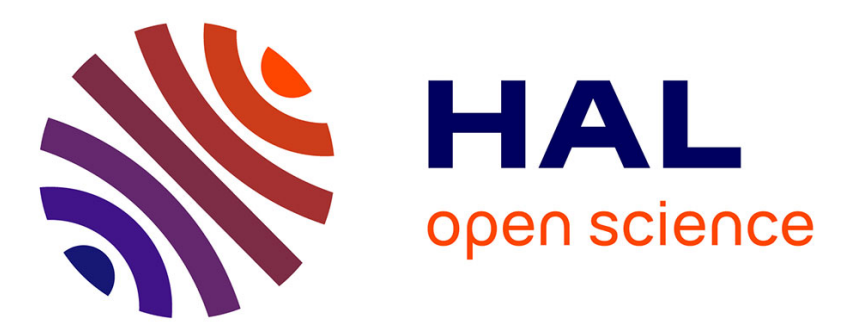

\title{
Short report: efficient oral infection of Culex pipiens quinquefasciatus by Rift Valley fever virus using a cotton stick support.
}

Sara Moutailler, Michele Bouloy, Anna-Bella Failloux

\section{To cite this version:}

Sara Moutailler, Michele Bouloy, Anna-Bella Failloux. Short report: efficient oral infection of Culex pipiens quinquefasciatus by Rift Valley fever virus using a cotton stick support.. American Journal of Tropical Medicine and Hygiene, 2007, 76 (5), pp.827-829. 10.4269/ajtmh.2007.76.827 . pasteur01697387

\section{HAL Id: pasteur-01697387}

\section{https://hal-pasteur.archives-ouvertes.fr/pasteur-01697387}

Submitted on 31 Jan 2018

HAL is a multi-disciplinary open access archive for the deposit and dissemination of scientific research documents, whether they are published or not. The documents may come from teaching and research institutions in France or abroad, or from public or private research centers.
L'archive ouverte pluridisciplinaire HAL, est destinée au dépôt et à la diffusion de documents scientifiques de niveau recherche, publiés ou non, émanant des établissements d'enseignement et de recherche français ou étrangers, des laboratoires publics ou privés.

$$
\text { Copyright }
$$




\title{
SHORT REPORT: EFFICIENT ORAL INFECTION OF CULEX PIPIENS QUINQUEFASCIATUS BY RIFT VALLEY FEVER VIRUS USING A COTTON STICK SUPPORT
}

\author{
SARA MOUTAILLER, MICHÈLE BOULOY, AND ANNA-BELLA FAILLOUX* \\ Unité Postulante Génétique Moléculaire des Bunyaviridés, Institut Pasteur, Paris, France
}

\begin{abstract}
Transmission experiments are essential to assess vector competence. In an attempt to study Rift Valley fever virus (RVFV) transmission in its arthropod vector, disseminated infection rates were measured in Culex pipiens quinquefasciatus exposed to Clone 13, an avirulent variant of RVFV. We compared the classic system of glass feeders covered with different membranes $(0-1 \%)$ with an alternative system in which a cotton stick is used as a support of a blood meal. The latter system showed the highest successful feeding rate $(80 \%)$. Using this system, we optimized two parameters to obtain the highest numbers of engorged females and thus the highest numbers of females with disseminated infection: 1) use of freshly collected washed erythrocytes and 2) duration of the extrinsic incubation period of at least 14 days after infection.
\end{abstract}

Rift Valley fever virus (RVFV), a Phlebovirus belonging to the family Bunyaviridae, is capable of infecting a wide range of hosts through the bite of infected mosquito vectors. This virus causes high abortion rates of pregnant females in livestock and in humans; it normally provokes a febrile disease. Rift Valley fever virus was first restricted to sub-Saharan Africa. ${ }^{1}$ However, in 1977, a major epidemic of RVFV occurred in $\mathrm{Egypt}^{2}$ and the mosquito Culex pipiens was incriminated as the vector. ${ }^{3}$ The $C x$. pipiens complex is known to be an efficient vector of arboviruses. ${ }^{3,4}$ The most representative members of the Culex complex are Cx. pipiens pipiens, which is found in Palearctic and Oriental regions and Culex pipiens quinquefasciatus, which is found at lower elevations in tropical regions. Whereas Culex p. pipiens has been involved in RVFV epidemics in Egypt, the virus has never been isolated from Culex p. quinquefasciatus. In west Africa, Culex p. quinquefasciatus has been suggested to have a role in human-tohuman transmission of RVFV. ${ }^{5}$

Vector competence experiments are typically used to assess variations in vector ability to transmit an arbovirus. ${ }^{6}$ Artificial feeding techniques are achieved using artificial feeding devices such as gauze pledgets, membrane feeder systems (chicken skin, hog intestine, dialysis tubing, latex condoms, Parafilm membranes) or droplets. Because $C x$. pipiens species feed with difficulty on artificial membranes, viremic animals could be used to infect mosquitoes and then to assess vector competence. Since RVFV is now considered a potential agent for bioterrorism, the use of viremic animals is often prohibited. To assess the ability of Culex $p$. quinquefasciatus to transmit RVFV and subsequently, the consequences of RVFV infection on $C x$. p. quinquefasciatus life history traits, we needed to obtain a high number of engorged females.

In this report, we compared two systems for engorgement of female mosquitoes: classic apparatus using three kinds of membrane and an alternative system composed of a cotton stick used as support for a blood meal. In addition to two factors known to affect positively the number of mosquitoes with disseminated infection (mosquitoes with virus that has

* Address correspondence to Anna-Bella Failloux, Unité Postulante Génétique Moléculaire des Bunyaviridés, Institut Pasteur, 25-28 Rue du Docteur Roux, 75724 Paris CEDEX 15, France. E-mail: afaillou@pasteur.fr disseminated from the midgut), i.e., the titer of the infectious blood meal $^{7}$ and the temperature during the extrinsic incubation period of females after exposure, ${ }^{8,9}$ we have tested 1) the quality of blood used (fresh or long term conserved erythrocytes) and 2) the duration of the extrinsic incubation period for exposed females.

Laboratory-reared $C x$. $p$. quinquefasciatus (SLAB strain) was originally obtained from California. ${ }^{10}$ Mosquitoes were maintained in the laboratory at $28 \pm 1{ }^{\circ} \mathrm{C}$, a relative humidity of $80 \%$, and a light:dark cycle of $16: 8$ hours. Larvae were reared until the adult stage in pans containing 1 liter of dechlorinated tap water supplemented with yeast tablets. Emerging adults were provided with $10 \%$ sucrose solution and fed weekly on anesthetized mice.

We used an avirulent variant of RVFV known as Clone 13. This virus was cloned by plaque purification from the 74HB59 RVF strain originally isolated in the Central African Republic. ${ }^{11}$ A monolayer of Aedes albopictus C6/36 cells was infected with stock Clone 13 at a multiplicity of infection of 0.1 plaque-forming units per cell for 72 hours at $27^{\circ} \mathrm{C}$. Cell infection was checked by indirect immunofluorescence assays using mouse ascitic fluids. When $80 \%$ of the cells were infected, the supernatant fluid was collected and kept at $-80^{\circ} \mathrm{C}$. Viral titer was estimated by plaque assay in Vero cells infected with serial 10 -fold dilutions. ${ }^{12}$

One-week-old female mosquitoes were starved for 24 hours prior to an infectious meal. Four batches of 40-70 females were blood fed. The meal consisted of two-thirds erythrocytes and one-third virus suspension with adenosine triphosphate added as phagostimulant $\left(5 \times 10^{-3} \mathrm{M}\right)$. After 30 minutes of blood feeding, fully-engorged females were transferred into small boxes and maintained with a $10 \%$ sucrose solution. To determine the dose of virus ingested, five mosquitoes were individually triturated in $0.5 \mathrm{~mL}$ of Dulbecco's modified Eagle's medium and filtered through a $0.22-\mu \mathrm{m}$ filter. Titration was achieved by plaque assay using serial 10 -fold dilution on Vero cells as previously described. ${ }^{12}$ At the end of the extrinsic incubation period (14 or 20 days), surviving females were killed and tested for RVFV by immunofluorescence assay on head squashes. ${ }^{13}$ For each assay, the number of females with disseminated infection was determined among the surviving females.

The classic membrane feeder system was similar to the one described by Rutledge and others, ${ }^{14}$ which consists of an in- 
verted water-jacketed glass funnel maintained at $37 \pm 1^{\circ} \mathrm{C}$ with a base opening $3.5 \mathrm{~cm}$ in diameter. The different membranes were stretched and placed over the opening. Females were allowed to feed through three types of membranes: chicken skin, Parafilm, and dialysis tubing.

The alternative system was a small plastic container $(57 \times$ $89 \mathrm{~mm}$ ) (Dominique Dutscher SAS, Brumath, France). The top is covered with a screen mesh and on the bottom a $3-\mathrm{cm}$ cotton stick, which is used in dentistry (Parotisroll, Roeko, Germany), is fixed. Three milliliters of infected blood meal was deposited on the cotton through the net with a syringe.

We evaluated the efficiency of two systems to engorge mosquitoes. We also tested two parameters to obtain optimum disseminated infection rates. To estimate the influence of blood quality, 100 engorged females for each type of blood meal were tested: defibrinated sheep erythrocytes, washed sheep erythrocytes, and washed rabbit erythrocytes. To measure the effect of duration of extrinsic incubation period, 30 engorged females per day until day 20 post-infection (pi) were tested. Percentages of infected females with a disseminated infection were compared using the $\mathrm{r} \times \mathrm{c}$ Fisher's exact test (Genepop software ${ }^{15}$ ). Analysis of variance was used for comparisons of means of infection rates (Statistica version 6.0; Statsoft, Tulsa, OK). Data were log-transformed to ensure normality.

Percentages of engorged females after feeding on the different systems are shown in Table 1 . When membrane feeders were used, only low percentages of engorged females were obtained: chicken skin $($ mean $=1 \%$, range $=0-5 \%$ ), Parafilm membrane $(0 \%, 0-1 \%)$, and dialysis tubing ( $0 \%)$. Conversely, our alternative system gave high percentages ranging from $70 \%$ to $95 \%$ (mean $=80 \%$ ). During the 30 minutes of blood feeding, no significant difference of viral titer was detected in the blood meal ingested by females and in the blood laid on the cotton stick support. For these reasons, feeding on the cotton stick has been adopted in subsequent experiments.

No significant difference between disseminated infection rates was detected $(P=0.38)$ using the three different blood meals. Higher disseminated infection rates were observed with freshly collected and washed erythrocytes, but sheep (13 of $91,14 \%$ ) or rabbit (13 of $100,13 \%)$ erythrocytes had no significant effect. Defibrinated sheep erythrocytes showed the lowest disseminated infection rate ( 7 of $85,8 \%$ ).

Disseminated infection rates of females during 20 days pi are shown in Figure 1. Higher disseminated infection rates were observed at day 13 (8 of 23, 35\%) and day 20 (13 of 28, $46 \%)$. The duration of the incubation period had a significant effect on disseminated infection rate $(\mathrm{F}=2.5136$, degrees of freedom $=20, P<0.001$, by analysis of variance). However,

TABLE 1

Percentages of engorged Culex pipiens quinquefasciatus using different artificial feeding systems*

\begin{tabular}{lcccc}
\hline & \multicolumn{3}{c}{ Membrane feeders } & \\
\cline { 2 - 4 } Assays & $\begin{array}{c}\text { Chicken } \\
\text { skin (no.) }\end{array}$ & $\begin{array}{c}\text { Parafilm } \\
\text { (no.) }\end{array}$ & $\begin{array}{c}\text { Dialysis } \\
\text { tubing (no.) }\end{array}$ & $\begin{array}{c}\text { Cotton stick } \\
\text { support (no.) }\end{array}$ \\
\hline 1 & $5(63)$ & $0(64)$ & $0(47)$ & $70(72)$ \\
2 & $0(60)$ & $0(60)$ & $0(50)$ & $95(43)$ \\
3 & $0(60)$ & $0(60)$ & $0(63)$ & $95(41)$ \\
4 & $0(44)$ & $1(70)$ & $0(58)$ & $73(70)$ \\
\hline \multirow{2}{*}{ No. = number of females tested. }
\end{tabular}

* No. $=$ number of females tested

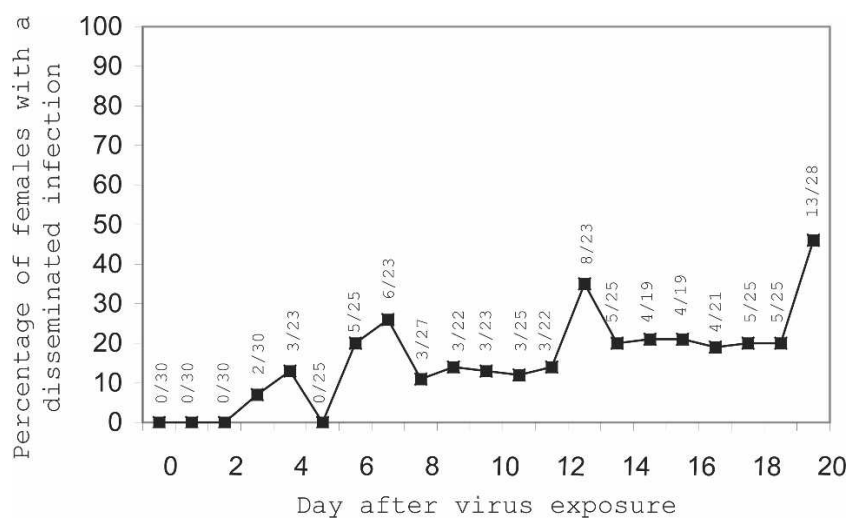

FIGURE 1. Effect of duration of incubation period on percentages of Culex pipiens quinquefasciatus with Rift Valley fever virus disseminated infection. Number of females with disseminated infection over the number of surviving females is indicated for each day postinfection after ingestion of $10^{8.5}$ plaque-forming units $/ \mathrm{mL}$ in a blood meal of defibrinated sheep erythrocytes and a temperature of $27^{\circ} \mathrm{C}$ during the extrinsic incubation period.

the standard deviations were so large that the difference in disseminated infection rates between 14 days pi and 20 days pi was negligible. When we estimated the relationship between the percentage of females with disseminated infection and the day after virus exposure, a positive correlation was observed ( $\mathrm{b}=+1.39)$ but this correlation was not statistically significant $\left(P>0.05, \mathrm{R}^{2}=0.56\right)$.

We have demonstrated that a system consisting of a cotton stick support for blood feeding results in higher percentages of engorged Culex p. quinquefasciatus females with successful RVFV disseminated infections of mosquitoes than the other systems tested. We have optimized parameters to obtain higher disseminated infection rates: 1) use of freshly collected washed erythrocytes for blood feeding and 2) maintenance of females during at least 14 days pi.

Although feeding of mosquitoes on laboratory animals was reported to results in a higher efficiency of mosquito disseminated infection, ${ }^{16}$ artificial feeding techniques are more convenient for evaluating vector competence for arboviruses. Meyer and others found that 10,000-fold more virus particles are necessary to infect $C x$. $p$. quinquefasciatus when fed on pledgets rather than on viremic animals. ${ }^{17} \mathrm{~A}$ minimum titer of $10^{8.5}$ plaque-forming units $/ \mathrm{mL}$ in an artificial infectious blood meal is needed to initiate RVFV disseminated infection in $C x$. p. quinquefasciatus and a temperature of $30^{\circ} \mathrm{C}$ gave the highest percentage of females with a disseminated infection. Moreover, some investigators obtained high disseminated infection rates with freshly collected blood, ${ }^{7}$ and others succeeded in using defibrinated sheep erythrocytes with their experimental conditions. ${ }^{18}$ The length of the extrinsic incubation period is inversely related to temperature during the incubation period; higher temperatures are assumed to enhance viral replication and dissemination. ${ }^{19}$ The system we have tested will be useful in future studies in which a high number of engorged mosquito vectors are required for studies on the consequences of RVFV infection.

Received July 3, 2006. Accepted for publication December 26, 2006.

Acknowledgments: We thank D. Coudrier and C. Tamietti for technical assistance, and F. Lacoste and P. Rassat for constant support. 
Financial support: This study was supported by a fellowship to Sara Montailler from the Fondation de France: Fonds Inckermann.

Authors' addresses: Sara Moutailler, Michèle Bouloy, and AnnaBella Failloux, Unité Postulante Génétique Moléculaire des Bunyaviridés, Institut Pasteur, 25-28 Rue du Dr. Roux, 75724 Paris CEDEX 15, France.

\section{REFERENCES}

1. Meegan JM, 1979. The Rift Valley fever epizootic in Egypt 197778. 1. Description of the epizootic and virological studies. Trans R Soc Trop Med Hyg 73: 618-623.

2. Gerrard SR, Nichol ST, 2002. Characterization of the Golgi retention motif of Rift Valley fever virus $\mathrm{G}(\mathrm{N})$ glycoprotein. $J$ Virol 76: 12200-12210.

3. Meegan JM, Khalil GM, Hoogstraal H, Adham FK, 1980. Experimental transmission and field isolation studies implicating Culex pipiens as a vector of Rift Valley fever virus in Egypt. Am J Trop Med Hyg 29: 1405-1410.

4. Kramer LD, Ebel GD, 2003. Dynamics of flavivirus infection in mosquitoes. Adv Virus Res 60: 187-232.

5. Marrama L, Spiegel A, Ndiaye K, Sall AA, Gomes E, Diallo M, Thiongane Y, Mathiot C, Gonzales JP, 2005. Domestic transmission of Rift Valley fever virus in Diawara (Senegal) in 1998. Southeast Asian J Trop Med Public Health 36: 1487-1495.

6. Hardy JL, Houk EJ, Kramer LD, Reeves WC, 1983. Intrinsic factors affecting vector competence of mosquitoes for arboviruses. Annu Rev Entomol 28: 229-262.

7. Vazeille-Falcoz M, Mousson L, Rodhain F, Chungue E, Failloux A-B, 1999. Variation in oral susceptibility to dengue type 2 virus of populations of Aedes aegypti from the islands of Tahiti and Moorea, French Polynesia. Am J Trop Med Hyg 60: 292299.

8. Turell MJ, 1993. Effect of environmental temperature on the vector competence of Aedes taeniorhynchus for Rift Valley fever and Venezuelan equine encephalitis viruses. Am J Trop Med Hyg 49: 672-676.
9. Brubaker JF, Turell MJ, 1998. Effect of environmental temperature on the susceptibility of Culex pipiens (Diptera: Culicidae) to Rift valley fever virus. J Med Entomol 35: 918-921.

10. Georghiou GP, Metcalf RL, Gidden FE, 1966. Carbamateresistance in mosquitoes. Selection of Culex pipiens fatigans Wiedemann ( $=C x$. quinquefasciatus Say) for resistance to Baygon. Bull World Health Organ 35: 691-708.

11. Muller R, Saluzzo JF, Lopez N, Dreier T, Turell M, Smith J, Bouloy M, 1995. Characterization of clone 13, a naturally attenuated avirulent isolate of Rift Valley fever virus, which is altered in the small segment. Am J Trop Med Hyg 53: 405-411.

12. Billecocq A, Vialat P, Bouloy M, 1996. Persistent infection of mammalian cells by Rift Valley fever virus. J Gen Virol 77: 3053-3062.

13. Kuberski TT, Rosen L, 1977. A simple technique for the detection of dengue antigen in mosquitoes by immunofluorescence. Am J Trop Med Hyg 26: 533-537.

14. Rutledge LCR, Ward RA, Gould DJ, 1964. Studies on the feeding response of mosquitoes to nutritive solutions in a new membrane feeder. Mosq News 24: 407-419.

15. Raymond M, Rousset F, 1995. Genepop (version 1.2): population genetics software for exact tests and ecumenicism. J Hered 86: 248-249.

16. Turell MJ, 1988. Reduced Rift valley fever virus infection rates in mosquitoes associated with pledget feedings. Am J Trop Med Hyg 39: 597-602.

17. Meyer RP, Hardy JL, Presser SB, 1983. Comparative vector competence of Culex tarsalis and Culex quinquefasciatus from the Coachella, Imperial, and San Joaquin Valleys of California for St. Louis encephalitis virus. Am J Trop Med Hyg 32: 305-311.

18. Molina-Cruz A, Gupta L, Richardson J, Bennett K, Black W IV, Barillas-Mury C, 2005. Effect of mosquito midgut trypsin activity on dengue-2 virus infection and dissemination in Aedes aegypti. Am J Trop Med Hyg 72: 631-637.

19. Turell MJ, Rossi CA, Bailey CL, 1985. Effect of extrinsic incubation temperature on the ability of Aedes taeniorhynchus and Culex pipiens to transmit Rift Valley fever virus. Am J Trop Med Hyg 34: 1211-1218. 